\title{
Efficacy of HIV/AIDS Related Educational Package on Awareness and High-Risk Behavior of Adolescent Students in Kathmandu Metropolitan City
}

\author{
K. C. Tulza ${ }^{1}$, Tilarupa Bhattarai ${ }^{2}$, Amit Arjyal $^{3}$, Sita Rijal ${ }^{4}$ \\ ${ }^{1}$ Department of Adult Nursing, Maharajgunj Nursing Campus, Institute of Medicine, Kathmandu, Nepal \\ ${ }^{2}$ Department of Psychiatric Nursing, Maharajgunj Nursing Campus, Institute of Medicine, Kathmandu, Nepal \\ ${ }^{3}$ Patan Academy of Health Sciences, Kathmandu, Nepal \\ ${ }^{4}$ Om Health Campus, Kathmandu, Nepal \\ Email: ^tulza.kc@hotmail.com
}

How to cite this paper: Tulza, K.C., Bhattarai, T., Arjyal, A. and Rijal, S. (2020) Efficacy of HIV/AIDS Related Educational Package on Awareness and High-Risk Behavior of Adolescent Students in Kathmandu Metropolitan City. Open Journal of Nursing, 10, 219-238.

https://doi.org/10.4236/ojn.2020.103015

Received: December 3, 2019

Accepted: March 14, 2020

Published: March 17, 2020

Copyright $\odot 2020$ by author(s) and Scientific Research Publishing Inc. This work is licensed under the Creative Commons Attribution International License (CC BY 4.0).

http://creativecommons.org/licenses/by/4.0/

(c) (i) Open Access

\begin{abstract}
Introduction: Human immunodeficiency virus (HIV) and acquired immune deficiency syndrome (AIDS) are among the most complex health problems of the $21^{\text {st }}$ century. Young people aged $15-24$ years are the HIV/AIDS at risk group. The objective of this study was to evaluate the effectiveness of an educational interventional program on knowledge on HIV/AIDS among adolescent students of higher secondary school in Kathmandu, Nepal. Methods: The study was the pre test - post test experimental study design with an experimental and a control group conducted in the randomly selected eighteen higher secondary schools. The intervention, educational package on HIV/AIDS, was provided to all grade twelve students in the intervention group from 1st September, 2017 to 2nd January, 2018. In total, 321 from the intervention group, and 283 from the control enrolled at baseline and over 95\% of these were followed up at posttest. The data were collected from self-administered questionnaires in English version and analyzed by using independence t-test and paired t-test. Results: Overall pretest knowledge of both intervention and control groups was comparable with $27.58 \pm 4.05$ and $28.53 \pm 3.77$ mean \pm standard deviation respectively. But statistical analysis showed significant higher knowledge $(\mathrm{P}=0.03)$ among control group. After the educational intervention, the mean knowledge score of control group increased by only 0.47 , whereas the same score increased by 11.57 and reached $39.15 \pm 3.7$ in post-test for intervention group. The difference in post-test score was statistically highly significant $(\mathrm{P}<0.001)$. The finding indicates that the educational intervention was effective in changing the HIV/AIDS knowledge
\end{abstract}


of students of intervention group. The differences in pre- and post-test knowledge scores of both intervention and control groups were statistically significant with $\mathrm{P}$-value of 0.000 and 0.003 respectively. The findings of sexual risk behavior showed that $6.7 \%$ of controls and $16.8 \%$ of intervention group students reported having sexual relations. Conclusion: Educational intervention was efficacious in improving awareness of adolescent students on HIV/AIDS. The study has also indicated that remarkable numbers of adolescents are practicing high risk behavior for HIV/AIDS like having early initiation sexual intercourse, multiple sex partners, using alcohol before intercourse etc. There is need to promote education program among higher secondary schools to multiply the effects of providing opportunities to equip students with factual information on HIV/AIDS.

\section{Keywords}

Adolescents, Educational Intervention, HIV/AIDS

\section{Introduction}

Human immunodeficiency virus (HIV) and acquired immune deficiency syndrome (AIDS) are among the most complex health problems of the 21 st century [1]. Young people (15 - 24 years old) are of international concern in the HIV/AIDS epidemic and are labelled "at risk" group. The importance of focusing on young people recognized at a global level by the 2002 United Nations General Assembly Special Session [2]. AIDS is a disease that in terms of its social problems, incidence and prevalence in active ages of society, high fatality rate and the cost of intensive care is considered among the main problems of the health care system; and control, prevention and care of patients are among the main activities that the health care institutions provide worldwide for this disease [3].

Globally, up to the end of 2014, 36.9 million people were living with HIV and 2 million people became newly infected. Over half of all new infections worldwide are among young people between the ages of 15 and 24 [4]. Adolescents aged 10 - 19 years of age accounting for nearly $22 \%$ of the population of Nepal are exposed to the risk of being victims of HIV/AIDS [5]. In Nepal, 13\% of all HIV cases are adolescents aged 14 - 19 years [6].

As a transitional step from children to adulthood, adolescence is a crucial period for fostering healthy attitudes and behaviors to protect people from diseases [1]. Studies have reported that co-existence of high risk behaviors, particularly unsafe sexual behavior, and influence of mass media on the perception of sex, degradation of traditional value, together with inadequate knowledge and major misconceptions related to HIV/AIDS, contributes young people to increased vulnerability to HIV infection [7] [8] [9]. Thus, fostering healthy behaviors among adolescents may be more essential for the prevention of HIV/AIDS and high-risk behaviors in the general population [1]. In addition, their opinions, at- 
titudes, and behaviors play a critical role in constructing a compassionate social environment free from discrimination for people living with HIV and AIDS [10].

Researches carried worldwide have shown that school-based education can serve as a powerful preventive tool for HIV/AIDS prevention activities [11] [12]. There is further evidence that HIV/AIDS education does not result in an earlier age of sexual debut, and in fact, it may delay the initiation of sexual activity and encourage use of protective behavior upon sexual initiation [12] [13]. In Nepal, schools are the primary locations where young people acquire knowledge, awareness and skills. School-based HIV/AIDS health education can be more efficiently delivered than other programs that help prevent the spread of AIDS. The objective of this study was to evaluate the effectiveness of an educational interventional program on knowledge and risk-behavior on HIV/AIDS among higher secondary school students in urban area of Kathmandu city, Nepal.

\section{Methods}

\subsection{Study Design}

The study consisted of pre test - post test experimental design with an experimental group and a control group using a self-administered questionnaire for both gender. The educational intervention provided to the experimental group was a brief one hour session and the study had a follow-up time of 3 months.

\subsection{Study Site and Population}

The study was conducted in the Kathmandu from 1st September, 2017 to 2nd January, 2018. It is the capital city of Nepal with a population of 1.5 million in the city proper [14]. The Kathmandu city was selected as research site because it is one of the urban and the largest metropolitan area that is likely to be the center of an epidemic. Among 257 higher secondary schools (HSS), 18 HSS, located and dispersed widely within Kathmandu Metropolitan City, were randomly selected and assigned, to either intervention or control group (9 in each). After being informed about the purpose of the study, all of 18 HSS agreed to participate. The experimental and control schools were similar with respect to curricula and organization, and average number of students per class. One section of class 12 of each school was selected with the lottery method. The population was adolescent students studying in class 12 of HSS. No other selection criteria were set for selecting the students. The students of the selected schools were informed of the purpose of the study before the intervention and a consent letter was given to all of them. Finally, all of the students of selected classes agreed to participate in the study.

\subsection{Pre Test}

A self-administered questionnaire was distributed to all the students of both intervention and control group for assessing their baseline knowledge and 
high-risk behavior regarding HIV/AIDS and collected back.

\subsection{Health Education Intervention}

The health education intervention module on HIV/AIDS was developed through the consultations with the experts in HIV/AIDS. Participants of experimental groups received a single session of HIV/AIDS class by trained teachers. The intervention consisted of single sessions for each class, each of 60 minutes duration which focused on basic facts about HIV/AIDS, epidemic situation in Nepal, and all over the world, transmission and non-transmission modes, high-risk behaviors, misconception related to HIV/AIDS, preventive measures, and availability of treatment. Medium of instruction was Nepali and English and power point slides along with charts were used as teaching aids. The control group was not given any intervention. Snacks were provided to all participants of both intervention and control group.

\subsection{Post Test Evaluation}

After a period of 3 months, a post test questionnaires were administered among the same students using the same questionnaire used for pre test. A lag period of 3 months was given after the health education, to assess the long term memory of the participants. After collecting back the filled questionnaire, a doubt clearance session was arranged for reinforcing the knowledge.

\subsection{Ethical Considerations}

The permission for conducting the research was obtained from the Institutional Review Board, Tribhuwan University, Institute of Medicine before commencement of the study. The research steps were explained and formal permission was obtained from the administration of selected 18 HSS. Informed written consent was also obtained from each respondent before data collection.

\subsection{Randomization Procedure}

The list of all names of HSS of the Kathmandu Metropolitan City served as the sampling frame. Participants were not aware of group assignment (single blind). The names of schools were randomly selected from the sampling frame of 257 HSS located within the Kathmandu Metropolitan City. The selected 18 HSS were randomly assigned using a computer generated table of random numbers into intervention and control groups (9 HSS in each group).

\subsection{Sample Size Calculation}

The sample size was calculated using odds ratio between the knowledge of experimental and control group of similar study done in Malaysia as 0.07 by Ibrahim, Rampal, Jamil, \& Jain (2012); assuming attrition rate of $20 \%$, the calculated sample size for this study was 604 . Total sample included in this study were 604 students aged 15 to 20 years. Eleven and twenty-one students dropped (total-5.29\%) 
from the post test from the intervention and control group respectively. Thus, the final sample size comprised of 572 students (310-intervention; 262-control) from both groups.

\subsection{Data Collection Procedures}

Data collection was carried out in the period 1st September, 2017 to 2nd January, 2018. A validated self-administered printed questionnaire was used as the test instrument among the both group. The questionnaire consisted of three main sections that required approximately 25 - 30 minutes to complete. A total of 604 students completed the test before the intervention, and 572 students were successfully followed up after the intervention. Questionnaires were handed out and collected by teams of researchers and trained research assistants in the class during school hours. Data were collected at baseline and 3 month's post-intervention.

\subsection{Instruments}

The test instrument was developed on the basis of literature review and HIV/AIDS/STD behavioral surveillance survey (BSS) questionnaire for youth [15]. The HIV-related knowledge questionnaire consisted of 34 items with "true" and "false" options. The responses were coded as 1 for a correct response and 0 for an incorrect or "false" response. Higher scores indicate accurate views on HIV/AIDS in this study. The questionnaire was developed into English languages. All questions were validated regarding language and comprehension of questions by a pre test study among the same population. The 3 parts of the questionnaire consisted of: 1) socio-demographic questions (8 questions on age, sex, address, ethnicity, religion and father's education and mother's education), 2) HIV/AIDS Knowledge (34 statements on HIV/AIDS transmission modes, non-transmission modes, prevention, treatment) and 3) HIV/AIDS-related Risk Behavior (13 questions on sexual exposure, sexual partner, condom use, and abuse of drug). The tests before and after the intervention were the same questionnaire, however, the students were not required to fill out the part on high-risk behaviors after the intervention test.

\subsection{Statistical Analysis}

Data were entered in, and analyzed using the Statistical Package for Social Sciences software (SPSS) version 16.0. Descriptive analysis was done on the socio-demographic characteristics and measured the rate of HIV/AIDS knowledge awareness. Pre intervention and post intervention knowledge scores of students were analyzed using paired t-test using SPSS and a p-value of less than 0.05 was considered as statistically significant.

\section{Results}

This study was done among 604 students. The mean age of respondent of inter- 
vention group was $17.42 \pm 1.070$ years and control group was $17.06 \pm 0.873$ years. Majority were of age group $15-17$ years in both intervention group (53.3\%) and control group (71.0\%). Female population was dominant in both groups (51.4\% and 53.4\% respectively). Majorities were from control (68.6\%) and intervention $(78.8 \%)$ group were migrant in the valley. Nearly half of respondents (46.4\% and $47.3 \%)$ were Brahman and Chhetri. Similarly, Hinduism was most followed (85.4\% and $84.1 \%)$ in both groups. Majority $(54.7 \%$ and $62.5 \%$ ) lived with their parents. Furthermore, $40.5 \%$ and $36.7 \%$ mothers of respondents had studied eight class or less in intervention and control group respectively, $37.4 \%$ and $39.2 \%$ fathers of respondents from intervention and control group had higher secondary education (Table 1).

In the pretest and posttest knowledge results of both control and the intervention group, majority of the control group respondents knew the cause, transmission and non-transmission routes of HIV/AIDS. It shows that there is nominal increase in between the pretest and posttest knowledge of the control group. Regarding the basic knowledge of AIDS in pre-test of the intervention group, majority (87.2\%) replied correctly on cause, $96.6 \%$ said sexual intercourse as a main transmission route, $80.4 \%$ replied hugging as a non transmission route. Regarding intervention group's response on posttest, it shows that most of the respondents of intervention group gave the correct response on the cause, transmission and non-transmission routes of HIV/AIDS during post test. It shows that there is increase in the knowledge after the post test of the intervention group ranging from $3.4 \%$ (main mode of transmission) to $44.5 \%$ (full form of AIDS) (Table 2). Majority of the control group respondents were known about the risk group of HIV/AIDS. Whereas regarding other variables, $73.1 \%$ said weight loss as major sign, more than half answered correctly on preventive measures and nearly half were known about the treatment of HIV/AIDS. There is minimal change in post test knowledge among control group.

Regarding the knowledge of risk group in pre-test of the intervention group, majority (85.0\%) identified multiple sex partners as main risk group. $68.5 \%$ said being faithful is the effective measure to prevent HIV/AIDS, and more than one third replied correctly about the treatment of HIV/AIDS. Regarding intervention group's response on posttest, most of the respondents of intervention group gave the correct response on risk groups, sign and symptoms, prevention and treatment of HIV/AIDS during post test. It shows that there is increase in the knowledge after the post test of the intervention group ranging from $15.0 \%$ (high risk for multiple sex partners) to $50.8 \%$ (prolonged diarrhea as sign) (Table 3).

The pre-test knowledge score of intervention and control groups shows that the baseline knowledge is significantly higher (0.03) in the control group than in the intervention group (Table 4). The post-test knowledge score of intervention and control groups. It shows that posttest knowledge score is significantly higher $(\mathrm{p}<0.001)$ in the intervention group than the control group as tested by Independent sample " $\mathrm{t}$ " test (Table 5). The mean and SD of control group at pre-test 
Table 1. Adolescents' socio-demographic characteristics.

\begin{tabular}{|c|c|c|c|c|c|}
\hline \multirow[t]{2}{*}{ Characteristics } & \multicolumn{2}{|c|}{$\begin{array}{l}\text { Intervention group } \\
\qquad(\mathrm{n}=321)\end{array}$} & \multicolumn{2}{|c|}{$\begin{array}{l}\text { Control group } \\
\quad(n=283)\end{array}$} & \multirow{2}{*}{$\begin{array}{c}\begin{array}{c}\text { Total } \\
(\mathrm{n}=604)\end{array} \\
\mathrm{n}(\%)\end{array}$} \\
\hline & $\mathbf{n}$ & $\%$ & $\mathbf{N}$ & $\%$ & \\
\hline \multicolumn{6}{|l|}{ Age (in years) } \\
\hline $15-17$ & 171 & 53.3 & 201 & 71.0 & $372(61.58)$ \\
\hline $18-21$ & 150 & 46.7 & 82 & 29.0 & $232(38.42)$ \\
\hline Mean age \pm SD & $17.42 \pm 1.070$ & & $17.06 \pm 0.873$ & & \\
\hline \multicolumn{6}{|l|}{ Gender } \\
\hline Male & 156 & 48.6 & 132 & 46.6 & $288(47.68)$ \\
\hline Female & 165 & 51.4 & 151 & 53.4 & $316(52.32)$ \\
\hline \multicolumn{6}{|l|}{ Marital Status } \\
\hline Married & 5 & 1.6 & 3 & 1.1 & $8(1.32)$ \\
\hline Single & 316 & 98.4 & 280 & 98.9 & $596(98.68)$ \\
\hline \multicolumn{6}{|l|}{ Residence } \\
\hline Inside valley & 68 & 21.2 & 89 & 31.4 & $157(26.0)$ \\
\hline Outside valley & 253 & 78.8 & 194 & 68.6 & $447(74.0)$ \\
\hline \multicolumn{6}{|l|}{ Ethnicity } \\
\hline Brahman \& Chhetri (parbatiya) & 149 & 46.4 & 134 & 47.3 & $283(46.86)$ \\
\hline $\begin{array}{l}\text { Brahman \& Chhetri } \\
\quad \text { (terai/madhesi) }\end{array}$ & 46 & 14.3 & 23 & 8.1 & $69(11.42)$ \\
\hline Dalit & 12 & 3.7 & 8 & 2.8 & $20(3.3)$ \\
\hline Janajati & 69 & 21.5 & 54 & 19.1 & $123(20.36)$ \\
\hline Newar & 24 & 7.5 & 61 & 21.6 & $85(14.07)$ \\
\hline Others & 21 & 6.5 & 3 & 1.1 & $24(3.98)$ \\
\hline \multicolumn{6}{|l|}{ Religion } \\
\hline Hindu & 274 & 85.4 & 238 & 84.1 & $512(84.8)$ \\
\hline Buddhist & 32 & 10.0 & 37 & 13.1 & $69(11.42)$ \\
\hline Muslim & 2 & 0.6 & 1 & 0.4 & $3(0.50)$ \\
\hline Christian & 13 & 4.0 & 7 & 2.5 & $20(3.31)$ \\
\hline \multicolumn{6}{|l|}{$\begin{array}{l}\text { Person with whom } \\
\text { participant live }\end{array}$} \\
\hline Parents & 175 & 54.5 & 177 & 62.5 & 352 \\
\hline Brother/sister & 85 & 26.5 & 50 & 17.7 & 135 \\
\hline Friends & 11 & 3.4 & 5 & 1.8 & 16 \\
\hline Relatives & 36 & 11.2 & 23 & 8.1 & 59 \\
\hline Others (Hostels) & 14 & 4.3 & 28 & 9.9 & 42 \\
\hline \multicolumn{6}{|l|}{ Education of Mother } \\
\hline No formal education & 107 & 33.3 & 76 & 26.9 & 183 \\
\hline 8 or less (Primary) & 130 & 40.5 & 104 & 36.7 & 234 \\
\hline Higher secondary & 69 & 21.5 & 74 & 26.1 & 143 \\
\hline Bachelor and above & 15 & 4.7 & 29 & 10.3 & 44 \\
\hline
\end{tabular}




\section{Continued}

\begin{tabular}{cccccc}
\hline Education of Father & & & & & \\
No formal education & 33 & 10.3 & 33 & 11.7 & 66 \\
8 or less (Primary) & 100 & 31.2 & 76 & 26.8 & 176 \\
Higher secondary & 120 & 37.4 & 111 & 39.2 & 231 \\
Bachelor and above & 68 & 21.1 & 63 & 22.2 & 131 \\
\hline
\end{tabular}

Table 2. Adolescents' knowledge on HIV/AIDS.

\begin{tabular}{|c|c|c|c|c|c|c|}
\hline \multirow{2}{*}{$\begin{array}{c}\text { Outcome } \\
\text { measures/Variables }\end{array}$} & \multicolumn{2}{|c|}{ Cont. Group } & \multirow{2}{*}{$\begin{array}{l}\text { Increase in } \\
\text { knowledge } \\
(\%)\end{array}$} & \multicolumn{2}{|c|}{ Int. Group } & \multirow{2}{*}{$\begin{array}{c}\text { Increase in } \\
\text { knowledge } \\
(\%)\end{array}$} \\
\hline & Pre test & Post test & & Pre test & Post test & \\
\hline \multicolumn{7}{|l|}{ Basic knowledge } \\
\hline Full form of AIDS & $16.6 \%$ & $17.6 \%$ & 1.0 & $12.5 \%$ & $52.6 \%$ & 40.1 \\
\hline Full form of HIV & $18.7 \%$ & $17.9 \%$ & -0.8 & $16.8 \%$ & $61.3 \%$ & 44.5 \\
\hline AIDS is caused by virus & $85.9 \%$ & $87.8 \%$ & 1.9 & $87.2 \%$ & $96.8 \%$ & 9.6 \\
\hline $\begin{array}{l}\text { HIV can be found } \\
\text { in semen, vaginal } \\
\text { secretions and blood }\end{array}$ & $77.4 \%$ & $83.9 \%$ & 6.5 & $84.1 \%$ & $97.7 \%$ & 13.6 \\
\hline $\begin{array}{l}\text { Cause of death of HIV } \\
\text { infected is mainly due } \\
\text { to recurrent infection }\end{array}$ & $70.3 \%$ & $68.7 \%$ & -1.6 & $70.1 \%$ & $88.1 \%$ & 18.0 \\
\hline \multicolumn{7}{|l|}{$\begin{array}{l}\text { Knowledge on } \\
\text { Transmission }\end{array}$} \\
\hline $\begin{array}{l}\text { Transmitted by } \\
\text { sexual intercourse }\end{array}$ & $92.2 \%$ & $92.7 \%$ & 0.5 & $96.6 \%$ & $100.0 \%$ & 3.4 \\
\hline $\begin{array}{l}\text { Sharing blade or } \\
\text { razors can transmit }\end{array}$ & $72.1 \%$ & $73.3 \%$ & 2.6 & $75.1 \%$ & $100.0 \%$ & 24.9 \\
\hline $\begin{array}{l}\text { Sharing syringe } \\
\text { and needles } \\
\text { can transmit HIV }\end{array}$ & $79.2 \%$ & $78.2 \%$ & 1.2 & $85.7 \%$ & $94.2 \%$ & 8.5 \\
\hline $\begin{array}{c}\text { Infected pregnant } \\
\text { women can } \\
\text { transmit HIV/AIDS }\end{array}$ & $77.7 \%$ & $80.9 \%$ & 3.2 & $79.8 \%$ & $93.9 \%$ & 14.1 \\
\hline $\begin{array}{c}\text { Breast milk } \\
\text { can transmit HIV }\end{array}$ & $68.9 \%$ & $69.5 \%$ & 0.6 & $69.5 \%$ & $94.5 \%$ & 25.0 \\
\hline \multicolumn{7}{|l|}{$\begin{array}{c}\text { Knowledge on } \\
\text { non-transmission }\end{array}$} \\
\hline $\begin{array}{l}\text { Shaking hands with } \\
\text { HIV infected person }\end{array}$ & $70.7 \%$ & $73.3 \%$ & 2.6 & $78.5 \%$ & $100.0 \%$ & 21.5 \\
\hline Coughing and spitting. & $73.1 \%$ & $75.2 \%$ & 2.1 & $70.1 \%$ & $92.9 \%$ & 22.8 \\
\hline Mosquito bites. & $56.2 \%$ & $58.8 \%$ & 2.6 & $62.0 \%$ & $89.7 \%$ & 27.7 \\
\hline $\begin{array}{l}\text { Eating together with } \\
\text { the HIV positive person }\end{array}$ & $74.9 \%$ & $77.1 \%$ & 2.2 & $77.9 \%$ & $96.8 \%$ & 18.9 \\
\hline Hugging & $79.5 \%$ & $80.9 \%$ & 1.4 & $80.4 \%$ & $97.4 \%$ & 17.0 \\
\hline Kissing & $73.9 \%$ & $74.8 \%$ & 0.9 & $74.8 \%$ & $92.3 \%$ & 17.5 \\
\hline
\end{tabular}


Table 3. Adolescents' knowledge on HIV/AIDS.

\begin{tabular}{|c|c|c|c|c|c|c|}
\hline \multirow{2}{*}{$\begin{array}{c}\text { Outcome } \\
\text { measures/Variables }\end{array}$} & \multicolumn{2}{|c|}{ Cont. Group } & \multirow{2}{*}{$\begin{array}{l}\text { Increase in } \\
\text { Knowledge } \\
(\%)\end{array}$} & \multicolumn{2}{|c|}{ Int. Group } & \multirow{2}{*}{$\begin{array}{c}\text { Increase in } \\
\text { Knowledge } \\
(\%)\end{array}$} \\
\hline & Pre test & Post test & & Pre test & Post test & \\
\hline \multicolumn{7}{|l|}{ Knowledge on Risk-group } \\
\hline $\begin{array}{l}\text { Multiple sex partners } \\
\text { (high risk) }\end{array}$ & $87.3 \%$ & $89.3 \%$ & 2.0 & $85.0 \%$ & $100.0 \%$ & 15.0 \\
\hline $\begin{array}{c}\text { Female sex workers } \\
\text { (low risk) }\end{array}$ & $75.6 \%$ & $77.5 \%$ & 1.9 & $70.1 \%$ & $89.7 \%$ & 19.6 \\
\hline $\begin{array}{l}\text { Clients of sex workers } \\
\text { (high risk) }\end{array}$ & $71.0 \%$ & $72.1 \%$ & 1.1 & $65.7 \%$ & $91.9 \%$ & 26.2 \\
\hline $\begin{array}{l}\text { People with STIs } \\
\text { (high risk) }\end{array}$ & $67.5 \%$ & $69.5 \%$ & 2.0 & $69.8 \%$ & $89.0 \%$ & 19.2 \\
\hline $\begin{array}{l}\text { Migrant people } \\
\text { (low risk) }\end{array}$ & $59.4 \%$ & $62.6 \%$ & 3.2 & $46.4 \%$ & $85.2 \%$ & 38.8 \\
\hline $\begin{array}{l}\text { Adolescent } \\
\text { (low risk) }\end{array}$ & $61.1 \%$ & $66.8 \%$ & 5.7 & $49.5 \%$ & $80.6 \%$ & 31.1 \\
\hline \multicolumn{7}{|l|}{$\begin{array}{l}\text { Knowledge on } \\
\text { Sign/Symptoms }\end{array}$} \\
\hline Prolonged diarrhea & $44.2 \%$ & $55.3 \%$ & 11.1 & $38.6 \%$ & $89.4 \%$ & 50.8 \\
\hline Prolonged Fever & $60.1 \%$ & $64.9 \%$ & 4.8 & $63.9 \%$ & $91.9 \%$ & 28.0 \\
\hline Excessive weight loss & $73.1 \%$ & $76.3 \%$ & 3.2 & $68.5 \%$ & $93.9 \%$ & 25.4 \\
\hline \multicolumn{7}{|l|}{ Knowledge on Prevention } \\
\hline $\begin{array}{l}\text { HIV/AIDS is a } \\
\text { preventable disease. }\end{array}$ & $51.6 \%$ & $56.5 \%$ & 4.9 & $44.2 \%$ & $82.3 \%$ & 38.1 \\
\hline $\begin{array}{c}\text { Abstinence can } \\
\text { prevent HIV/AIDS. }\end{array}$ & $60.4 \%$ & $63.0 \%$ & 2.6 & $54.8 \%$ & $86.8 \%$ & 32.0 \\
\hline $\begin{array}{l}\text { Condoms do not } \\
\text { reduce the chance }\end{array}$ & $69.3 \%$ & $71.4 \%$ & 2.1 & $56.7 \%$ & $90.0 \%$ & 33.3 \\
\hline $\begin{array}{l}\text { Being faithful is the } \\
\text { effective measure to } \\
\text { prevent HIV/AIDS }\end{array}$ & $72.8 \%$ & $74.0 \%$ & 1.2 & $68.5 \%$ & $89.7 \%$ & 21.2 \\
\hline $\begin{array}{l}\text { Carefully tested blood } \\
\text { transfusions do } \\
\text { not reduce the } \\
\text { chance of HIV/AIDS }\end{array}$ & $54.4 \%$ & $57.3 \%$ & 2.9 & $41.4 \%$ & $77.1 \%$ & 35.7 \\
\hline \multicolumn{7}{|l|}{ Knowledge on Treatment } \\
\hline $\begin{array}{l}\text { ARV drug therapy } \\
\text { cures HIV/AIDS. }\end{array}$ & $42.4 \%$ & $44.7 \%$ & 2.3 & $39.9 \%$ & $69.7 \%$ & 29.8 \\
\hline $\begin{array}{l}\text { ARV is needed only } \\
\text { for few months. }\end{array}$ & $48.4 \%$ & $50.8 \%$ & 2.4 & $34.9 \%$ & $72.9 \%$ & 38.0 \\
\hline $\begin{array}{l}\text { ARV is only for } \\
\text { prolonging life of } \\
\text { the HIV patients. }\end{array}$ & $44.9 \%$ & $45.4 \%$ & 0.5 & $39.3 \%$ & $78.4 \%$ & 39.1 \\
\hline $\begin{array}{l}\text { Healthy life styles help } \\
\text { to improve the quality of } \\
\text { life of HIV/AIDS patients. }\end{array}$ & $58.0 \%$ & $55.7 \%$ & -2.3 & $57.6 \%$ & $90.3 \%$ & 32.7 \\
\hline
\end{tabular}


Table 4. Pre-test knowledge scores of intervention and control groups.

\begin{tabular}{cccccc}
\hline Groups & Mean & SD & SE & $t$ & $\mathrm{p}$ \\
\hline Intervention Group $(\mathrm{n}=321)$ & 27.58 & 4.05 & 0.22 & & \\
Control Group $(\mathrm{n}=283)$ & 28.53 & 3.77 & 0.22 & & 0.03 \\
\hline
\end{tabular}

Table 5. Post-test knowledge scores of intervention and control groups.

\begin{tabular}{cccccc}
\hline Groups & Mean & SD & SE & t & $\mathrm{p}$ \\
\hline Intervention Group $(\mathrm{n}=310)$ & 39.15 & 3.27 & 0.18 & 31.0 & \\
Control Group $(\mathrm{n}=262)$ & 29.55 & 3.92 & 0.24 & 31.4 & 0.000 \\
\hline
\end{tabular}

was $28.51 \pm 3.79$, which is lower than the mean and SD $29.63 \pm 3.97$ of post-test. $\mathrm{P}$-value shows that there is significant difference between the pre-test and post-test level of knowledge (Table 6). The mean and SD of the intervention group at pre-test was $27.59 \pm 4.06$, which is lower than the mean and SD $38.77 \pm$ 3.82 of post-test. It shows that there is significant difference between the pre-test and post-test level of knowledge in the intervention group (Table 7).

The findings of sexual risk behavior show that $6.7 \%$ of controls and $16.8 \%$ of intervention group students reported having sexual relations. Among sexually active students, 12 (54.5\%) of controls and $47(74.7 \%)$ were having sex for two or more times during the past 12 months. $77.2 \%$ and $58.8 \%$ of them had had sex with two or more people in the past 12 months in control and intervention group respectively. $72.8 \%$ of controls and $69.8 \%$ of intervention group had always used condom. Only $4.5 \%$ of controls and $15.8 \%$ of intervention groups had taken alcohol before having sex. Majority (68.1\% controls; 79.3\%-intervention) had sexual relationship with their girlfriend. Extremely few $(0.4 \%$ in control; $3.7 \%$ in int.) had taken drugs in past 12 months. Likewise, $0.4 \%$ and $25.0 \%$ of them had shared needle and $1.1 \%$ and $3.4 \%$ had been tested for HIV in the control and intervention group respectively (Table 8 ).

\section{Discussion}

In baseline, $85.9 \%$ from control group and $87.2 \%$ from experimental group could answer that AIDS is caused by a virus, but greater percentage (94.8\%) of students were aware of this information before the health education intervention in a study done by Sugathan and Swaysi [16].

In pre-test, $56.2 \%$ and $62 \%$ of students from control and intervention group could state that mosquito bite cannot transmit HIV/AIDS, which increased to $58.8 \%$ and $89.7 \%$ in both groups respectively. Similar types of finding was reported by Cheng et al., where insect bites' no risk of transmitting HIV was significantly higher in the intervention group (85.5\%) than in the control group (27.6\%) at post-test [10].

As for transmission of HIV/AIDS, nearly equal (68.9\% and 69.5\%) were aware of possibility of transmission to baby by lactating mother in both groups in pretest but, the percentage of correct response increased in intervention group 
Table 6. Comparison of pre and post test HIV/AIDS knowledge scores of control group.

\begin{tabular}{cccccc}
\hline Phases of Testing (Control Group) & Mean & SD & $t^{*}$ & $\mathrm{p}$ & $\mathrm{n}$ \\
\hline Total pre score & 28.51 & 3.79 & & & $\mathrm{n} 1(283)$ \\
Total post score & 29.63 & 3.97 & & & $\mathrm{n} 2(262)$ \\
\hline
\end{tabular}

${ }^{\star}$ Paired $\mathrm{t}$ test.

Table 7. Comparison of pre and post test HIV/AIDS knowledge scores of intervention group.

\begin{tabular}{cccccc}
\hline Phases of Testing (Intervention Group) & Mean & SD & t & P & $\mathrm{n}$ \\
\hline Total pre score & 27.59 & 4.06 & & & $\mathrm{n} 1(321)$ \\
Total post score & 38.77 & 3.82 & & & $\mathrm{n} 2(310)$ \\
\hline
\end{tabular}

Table 8. Sexual behavior of higher secondary students.

\begin{tabular}{|c|c|c|}
\hline \multirow{2}{*}{ Variables } & \multirow{2}{*}{$\begin{array}{l}\text { Cont. group } \\
\text { Pre test n (\%) }\end{array}$} & \multirow{2}{*}{$\begin{array}{c}\text { Int. group } \\
\text { Pre test n (\%) }\end{array}$} \\
\hline & & \\
\hline \multicolumn{3}{|l|}{ Have boyfriend/girlfriend } \\
\hline Yes & $89(31.4)$ & $141(43.9)$ \\
\hline No & $194(68.6)$ & $180(56.1)$ \\
\hline \multicolumn{3}{|c|}{ Is he/she your sexual partner? (Pre test $n=283$ ) } \\
\hline Yes & $19(6.7)$ & $54(16.8)$ \\
\hline No & $264(93.3)$ & $267(83.2)$ \\
\hline \multicolumn{3}{|c|}{ Ever been forced to have sexual things? } \\
\hline Yes & $33(11.7)$ & $33(10.3)$ \\
\hline No & $250(88.3)$ & $288(89.7)$ \\
\hline \multicolumn{3}{|c|}{ Ever been forced to have sex? } \\
\hline Yes & $21(7.4)$ & $38(11.8)$ \\
\hline No & $262(92.6)$ & $283(88.2)$ \\
\hline \multicolumn{3}{|c|}{ Frequency of sexual behaviors in the past 12 months $(n=22)$} \\
\hline One only & $10(45.5)$ & $16(25.3)$ \\
\hline Two or more & $12(54.5)$ & $47(74.7)$ \\
\hline \multicolumn{3}{|c|}{$\begin{array}{l}\text { Number of people have you had } \\
\text { sex in the past } 12 \text { months }(n=22)\end{array}$} \\
\hline One only & $17(77.2)$ & $37(58.8)$ \\
\hline Two or more & $5(22.8)$ & $26(41.2)$ \\
\hline \multicolumn{3}{|c|}{ Frequency of using condoms } \\
\hline Always & $16(72.8)$ & $44(69.8)$ \\
\hline More than half time & $3(13.6)$ & $7(11.1)$ \\
\hline Never used & $3(13.6)$ & $12(19.1)$ \\
\hline
\end{tabular}




\section{Continued}

Use of alcohol or drugs before sex?

$\begin{array}{lcc}\text { Yes } & 1(4.5) & 10(15.8) \\ \text { No } & 21(95.5) & 53(84.2)\end{array}$

Person involved in the sexual activities in the past 12 months

$\begin{array}{ccc}\text { Girlfriend } & 15(68.1) & 50(79.3) \\ \text { Boyfriend } & 3(13.7) & 8(12.7) \\ \text { Others (sex workers, friend) } & 4(18.2) & 5(8.0) \\ \text { Yes } & & \\ \text { No } & 1(0.4) & 12(3.7) \\ & 282(99.6) & 309(96.3)\end{array}$

Frequency of using drugs in the past 12 months

One only

Two or more

Had ever shared the needle?

Yes

$1(0.4) \quad 3(25.0)$

Ever been tested for HIV?

$\begin{array}{ccc}\text { Yes } & 3(1.1) & 11(3.4) \\ \text { No } & 280(98.9) & 310(96.6)\end{array}$

(95.5\%) after education. Similar finding was reported by a study done in rural north Kerala of India [17]. In present study, more than $90 \%$ on both groups could answer that sexual intercourse with HIV infected can transmit the HIV/AIDS at baseline. In other areas of transmission and non-transmission, around $70 \%-80 \%$ of respondents from both groups answered correctly in pre-test. The increment of correct response in post-test was ranging from 1.2\% to $6.5 \%$ in control group, and $13.6 \%$ to $44.5 \%$ intervention group. Students of both groups had an intermediate level of knowledge regarding risk groups for HIV/AIDS. However, the intervention group students showed an increased rate of knowledge in post intervention evaluation. In this study, similar results were observed on signs and symptoms of HIV/AIDS also where students gained increased knowledge after health education.

There were $51.6 \%$ students in control and $44.2 \%$ students in experimental group who could correctly answered that HIV/AIDS is a preventable disease which increased to $56.5 \%$ in control group and $82.3 \%$ in intervention group after health education. Sugathan and Swaysi had noted that $92.4 \%$ of students were aware of its preventable nature and reached to $93.6 \%$ in post-test [15]. Similarly, the same study has revealed that $94.8 \%$ of students were having knowledge that there is no complete cure for AIDS before the intervention [15]. Contrary to this, present study showed that only $42.4 \%$ of control group and $39.9 \%$ intervention group students were aware of this fact prior to the educational intervention.

Overall pretest knowledge of both intervention and control groups was com- 
parable with $27.58 \pm 4.05$ and $28.53 \pm 3.77$ mean \pm SD respectively. But statistical analysis showed significant higher knowledge $(P=0.03)$ among control group students than their counterparts in intervention group. After the educational intervention, the mean knowledge score of control group increased by only 0.47 , whereas the same score increased by 11.57 and reached $39.15 \pm 3.7$ in post-test for intervention group. The difference in post-test score was statistically highly significant $(\mathrm{P}<0.001)$. The difference in pre and post-test knowledge scores of both intervention and control groups were statistically significant with $\mathrm{P}$-value of 0.000 and 0.003 respectively tested by paired t test. Similar finding was noted in a study done in Trinidad and Tobago among school students where both groups had statistically significant higher posttest scores on the variables of knowledge, susceptibility, and self-efficacy as it pertains to youth being able to speak about condoms and condom use [18]. Contrary to the present study, this study had covered wide dimensions of HIV/AIDS knowledge, practice, attitude and self-efficacy. A systemic review of 17 similar scientific papers regarding effectiveness of school based education on HIV knowledge and practice concluded that out of the 17 studies, 10 assessed the intervention's effects on knowledge. All 10 studies indicated that certain interventions could increase knowledge about one or more subjects which included STIs/HIV and their prevention [19].

Regarding the high risk sexual behavior, $6.7 \%$ of controls and $16.8 \%$ of intervention group reported having sexual relations. In support with this finding is a study where $11 \%$ reported that they had had sex before the age of sixteen [20]. Similar finding was reported in study done in Ethiopia [21]. In present study, nearly same (7.4\% and $11.8 \%)$ students reported being forced for sex in control and intervention group respectively. Among sexually active students, $54.5 \%$ of controls and $74.7 \%$ were having sex for two or more times during the past 12 months. Among them, $77.2 \%$ and $58.8 \%$ of them had had sex with two or more people in the past 12 months in control and intervention group respectively. A study done in Nigeria among high school students revealed comparatively smaller proportion (20.5\%) of the respondents who committed sex had sex with two and more sexual partners in their life time, $8.7 \%$ committed sex with more than one sexual partner [22]. Among the sexually active students, $72.8 \%$ of controls and $69.8 \%$ of intervention group had always used condom. Even $4.5 \%$ of controls and $15.8 \%$ of intervention groups had taken alcohol before having sex. Extremely few ( $0.4 \%$ in control; $3.7 \%$ in int.) had taken drugs in past 12 months.

\section{Conclusion}

The research finding showed that, there was significant difference between mean score of pre and post-test knowledge on HIV/AIDS, with higher knowledge in post-test of intervention group than their counterparts in control group. By this finding, the research hypothesis "there is significant difference on awareness level of adolescent students about HIV/AIDS before and after educational intervention among intervention and control group" has been accepted. It concludes that the educational intervention was efficacious in improving awareness of 
adolescent students on HIV/AIDS. The study has also indicated that remarkable numbers of adolescents are practicing high risk behavior for HIV/AIDS like having early initiation sexual intercourse, multiple sex partners, using alcohol before intercourse etc. and very few sexually active students have tested their HIV/AIDS status.

\section{Recommendation}

Based on the finding of this study, it is expedient that HIV/AIDS education to students be provided during their higher secondary level study period. Decision-makers as well as school principal and teachers should realize that school education is an effective solution to prevent the spread of the HIV/AIDS epidemic. HIV/AIDS education should form part of school curriculum. Students should be periodically assessed for high risk sexual behavior. Counseling and referral service should be provided to the students with high risk behavior.

\section{Limitations}

Firstly, the population of the study only included Grade Twelve students from each selected HSS and did not include adolescents not attending such schools. Therefore, the results cannot be used to make a generalization about out-of-school adolescents. The honesty of some responses should also be interpreted with caution, especially those that pertain to questions about sex activities and drug abuse, because the data were self-reported by the students. Future research needs to focus on long-term and multi-stage interventions on the knowledge of HSS students about HIV/AIDS. Despite all of these limitations, this study might be a reasonable source of information for researchers and policymakers.

\section{Acknowledgements}

Authors would like to thank the University Grant Commission for the grant which helped in successful completion of this study. We would also like to thank Assoc. Prof. Krishna G.C., Department of Public Health, Patan Academy of Health Science, Assoc. Prof. Prem Pant, Department of Bio-statistics, Nepal Medical College and Teaching Hospital, Kathmandu who provided insight and expertise that greatly assisted the research. Many thanks go to the Principals, all students and administrative staffs of all the eighteen higher secondary schools of Kathmandu and Manisha Rijal for the cooperation provided throughout the data collection period and data analysis.

\section{Funding}

University Grant Commission, Sanothimi, Bhaktapur, Nepal.

\section{Conflicts of Interest}

None declared. 


\section{References}

[1] Gao, X., Wu, Y., Zhang, Y., Zhang, N., Tang, J., Qiu, J., Lin, X. and Du, Y. (2012) Effectiveness of School-Based Education on HIV/Aids Knowledge, Attitude, and Behavior among Secondary School Students in Wuhan, China. PLoS ONE, 7, e44881. https://doi.org/10.1371/journal.pone.0044881

[2] Choudhary, H.A., Ali, R.A. and Altaf, S. (2015) Knowledge, Behaviour and Attitudes Regarding Hiv/Aids among Undergraduate Students in an Irish University. International Journal of Surgery and Medicine, 1, 58-66. https://doi.org/10.5455/ijsm.20150814034728

[3] Peyman, N. and Jangi, M. (2015) The Effect of Educational Intervention on Knowledge, Attitude and Performance of High School Girl Students about AIDS. International Journal of Pediatrics, 3, 833-839.

[4] UNAIDS (2015) All in to End Adolescent AIDS. http://www.unaids.org/sites/default/files/media_asset/20150217_ALL_IN_brochure. pdf

[5] Pandey, A., Umashankar, S. and Maharja, O. (2014) Effects of Different Educational Intervention on Awareness about HIV/Aids among School Going Adolescents. International Journal of Science Technology \& Engineering, 1, 39-44.

[6] Banjade, S. and Pandey, A. (2015) Knowledge on HIV/Aids among Secondary Level Student of Sandhikharka vdc, Arghakhanchi. Point Journal of Medicine and Medical Research, 1, 10-17.

[7] Sommartab, J. and Sotac, C. (2013) The Effectiveness of a School-Based Sexual Health Education Program for Junior High School Students in Khon Kaen, Thailand. Procedia-Social and Behavioral Sciences, 91, 208-214.

https://doi.org/10.1016/j.sbspro.2013.08.419

[8] Ibrahim, N., Rampal, L., Jamil, Z. and Zain, A.M. (2012) Effectiveness of Peer-Led Education on Knowledge, Attitude and Risk Behavior Practices Related to HIV among Students at a Malaysian Public University-A Randomized Controlled Trial. Preventive Medicine, 55, 505-510. https://doi.org/10.1016/j.ypmed.2012.09.003

[9] Tan, X., Pan, J., Zhou, D., Wang, C. and Xie, C. (2007) HIV/AIDS Knowledge, Attitudes and Behaviors Assessment of Chinese Students: A Questionnaire Study. International Journal of Environmental Research and Public Health, 4, 248-253. https://doi.org/10.3390/ijerph2007030009

[10] Cheng, Y., Lou, C.H., Mueller, L.M., Zhao, S.L., Yang, J.H., Tu, X.W. and Gao, E.S. (2008) Effectiveness of a School-Based AIDS Education Program among Rural Students in HIV High Epidemic Area of China. Journal of Adolescent Health, 42, 184-191. https://doi.org/10.1016/j.jadohealth.2007.07.016

[11] UNAIDS (2007) Report on the Global AIDS Epidemic. UNAID, Geneva.

[12] Liao, W., Jiang, J.M., Yang, B., Zeng, X. and Liao, S.S. (2010) A Life-Skills-Based HIV/AIDS Prevention Education for Rural Students of Primary Schools in China: What Changed? What Have We Learned? Biomedical and Environmental Sciences, 23, 409-419. https://doi.org/10.1016/S0895-3988(10)60083-9

[13] Srivastava, A., Mahmood, S.E., Mishra, P., Shrotriya, V.P. and Shaifali, I. (2011) Adolescence Awareness: A Better Tool to Combat HIV/Aids. National Journal of Community Medicine, 2, 86-90.

[14] Central Bureau of Statistics (CBS) (2012) National Population Census 2011. Kathmandu November, 2012.

[15] Family Health International (2000) HIV/AIDS/STD Behavioral Surveillance Surveys 
(BSS) Questionnaire for Youth.

https://www.who.int/hiv/strategic/en/bss_fhi2000.pdf?ua=1

[16] Sugathan, S. and Swaysi, M. (2012) Knowledge about HIV/AIDS among Premedical Students in Misurata, Libya and the Effectiveness of a Health Education Intervention. Journal of Community Medicine \& Health Education, 2, 187. https://doi.org/10.4172/2161-0711.1000187

[17] Antherjanam, D., Anitha, S.S., Jayasree, A.K., Karunakaran, U., Divakaran, B., Suma, Alesh, O.P., et al. (2014) Knowledge and Attitude, among High School and Higher Secondary Students in a Rural Area of North Kerala, on HIV and Its Spread. Nepal Journal of Epidemiology, 4, No. 2.

[18] Jones, V., Modeste, N., Marshak, H.H. and Fox, C. (2013) The Effect of HIV/AIDS Education on Adolescents in Trinidad and Tobago. ISRN Infectious Diseases, 2013, Article ID: 691054. https://doi.org/10.5402/2013/691054

[19] Alfred, L. (2016) The Efficacy of HIV and Sex Education Interventions among Youths in Developing Countries: A Review. Public Health Research, 6, 1-17.

[20] Adhikari, R. (2010) Are Nepali Students at Risk of HIV? A Cross-Sectional Study of Condom Use at First Sexual Intercourse among College Students in Kathmandu. Journal of International AIDS Society, 13, 7. https://doi.org/10.1186/1758-2652-13-7

[21] Dingeta, T., Oljira, L. and Assefa, N. (2012) Patterns of Sexual Risk Behavior among Undergraduate University Students in Ethiopia: A Cross-Sectional Study. Pan African Medical Journal, 12, 33. http://www.panafrican-med-journal.com

[22] Daka, D. and Shaweno, D. (2014) Magnitude of Risky Sexual Behavior among School Adolescents in Ethiopia: A Cross Sectional Study. Journal of Public Health and Epidemiology, 6, 211-215. https://doi.org/10.5897/JPHE2014.0639 


\section{Appendix A}

Self administered questionnaire on efficacy of HIV/AIDS related educational package on awareness and high-risk behavior of adolescent students in kathmandu metropolitan city.

\section{Part I}

\section{Demographic Information}

Instructions: Read each question carefully. Mark your answers in the square next to the questions. Mark one answer for each question, unless the instructions says to mark more than one answer.

1) How old are you today? (Please mention your completed years)

a.

2) Gender
a. Male
b. Female

3) Where is your permanent home address?

a. Inside Kathmandu valley b. Outside Kathmandu valley

4) Ethnicity

a. Brahmans and Chhetris (parabatiya)

b. Brahmans and Chhetris (Tarai/Madhesi)

c. Dalits d. Janajati

e. Newar f. Others (please specify)

5) Religion

a. Hindu b. Buddhist

c. Muslim d. Christian

6) You live with,

a. Parents b. Brother/Sister

c. Friends d. Relatives

e. Hostel f. Others (please specify)

7) Educational level of mother

a. No formal education (Cannot read and write)

b. She completed 8th grade or less than 8 th grade

c. She completed higher secondary level

d. She completed bachelor level

e. Others (please specify)

8) Educational level of father

a. Cannot read and write

b. He completed 8th grade or less than 8 th grade

c. He completed higher secondary level

d. He completed bachelor level

e. Others (please specify)

\section{Part II}

Information Related to Knowledge about HIV/AIDS

1) Where did you hear about HIV/AIDS? (Choose all that apply)
a. School
b. Mass Medias (TV/Radio/internet) 

c. Peers (Friends)
d. Health personnel
e. Others

2) The full form of AIDS is:

a. A-

b. I-

c. D-

d. S-

3) The full form of HIV is:
a. H-
b. I-
c. V-

4) AIDS is caused by:
a. Virus
b. Bacteria
c. Fungi
d. Protozoa

Please tick $(\sqrt{ })$ whether the following statements are true or false

\begin{tabular}{|c|c|c|}
\hline S.N. & Statements & True \\
\hline 1. & HIV can be transmitted by sexual intercourse. & \\
\hline 2. & HIV can be found in semen, vaginal secretions and blood. & \\
\hline 3. & Sharing blade or razors can transmit HIV. & \\
\hline 4. & Sharing syringe and needles can transmit HIV. & \\
\hline 5. & HIV is transmitted through shaking hands with HIV infected person. & \\
\hline 6. & HIV can be transmitted by mosquito bites. & \\
\hline 7. & HIV can be transmitted by coughing and spitting. & \\
\hline 8. & $\begin{array}{l}\text { HIV can be transmitted by eating together with the HIV } \\
\text { positive person in same utensil. }\end{array}$ & \\
\hline 9. & HIV can be transmitted by hugging with the HIV positive person. & \\
\hline 10. & HIV can be transmitted by kissing with the HIV positive person. & \\
\hline 11. & $\begin{array}{l}\text { There is a chance to transmit HIV/AIDS while giving child birth } \\
\text { by HIV infected mother. }\end{array}$ & \\
\hline 12. & $\begin{array}{l}\text { There is a chance to transmit HIV/AIDS through breast feeding } \\
\text { from HIV positive mother to her new born baby. }\end{array}$ & \\
\hline 13. & People having multiple sex partners are at high risk for HIV/AIDS. & \\
\hline 14. & Female sex workers are at low risk for HIV/AIDS transmission. & \\
\hline 15. & Clients (customers) of sex workers are at high risk for HIV/AIDS. & \\
\hline 16. & $\begin{array}{l}\text { People who have other sexually transmitted infections } \\
\text { are at high risk for HIV/AIDS. }\end{array}$ & \\
\hline 17. & $\begin{array}{l}\text { Seasonal labor migrants (migrant workers) are at low risk for } \\
\text { HIV/AIDS. }\end{array}$ & \\
\hline 18. & Adolescents are at low risk for HIV infection. & \\
\hline 19. & $\begin{array}{l}\text { One of the main signs of AIDS is prolonged diarrhoea for } \\
\text { more than one month. }\end{array}$ & \\
\hline 20. & Prolonged fever is also the main sign of HIV/AIDS. & \\
\hline 21. & $\begin{array}{l}\text { Excessive weight loss (more than } 10 \% \text { of body weight) } \\
\text { is also the main sign of HIV/AIDS. }\end{array}$ & \\
\hline 22. & $\begin{array}{l}\text { Cause of death of HIV infected person is mainly due to recurrent } \\
\text { infection (any kind). }\end{array}$ & \\
\hline
\end{tabular}




\section{Continued}



\section{Part III}

\section{High Risk Behaviors related to HIV/AIDS}

1) Are you married?
a. Yes
b. No

2) Do you have boyfriend/girlfriend?
a. Yes
b. No

3) Is he/she your sexual partner?
a. Yes
b. No.

4) Has someone ever forced you to have sexual things you didn't want to?
a. Yes
b. No

5) Has someone ever forced you to have sex?
a. Yes
b. No

6) How many times have you had sex in the past 12 months?

a. I have not had sex in the past 12 months
b. 1 time
c. 2 times
d. 3 times
e. 4 times

\section{f. 5 times or more}

7) How many people have you had sex with the past 12 months?

a. I have never had sex
b. 1 person
c. 2 person
d. 3 person
e. 4 person

f. 5 person or more

8) Of all the times you have had sex, how often did you use condoms?

a. I have never had sex

b. We always used condoms

c. We used condoms more than half the time

d. We used condoms half the time

e. We used condoms less than half the time

f. We never used condoms

9) The last time you had sex, did you drink alcohol or use drugs before you had sex? 

a. I have never had sex
b. Yes
c. No

10) In the past 12 months, who was the person you were involved in the sexual activities? (You can tick more than one option)
a. I have never had sex in the past 12 months.
b. Girlfriend
c. Boyfriend
d. Female sex workers
e. Friend
f. Relative
g. Family member

11) In the past 12 months, have you used drugs (illegal)?
a. Yes
b. No
12) If yes, what type of drugs had you used?
a. Tablets
Yes/No
b. Syrup (liquid drugs)
Yes/No
c. Injection
Yes/No
d. Sniffing drugs
Yes/No

13) How many times have you had drugs (illegal) in the past 12 months?

a. I have not had drugs in the past 12 months
b. 1 time
c. 2 times
d. 3 times
e. 4 times

\section{f. 5 times or more}

14) If you had used injectable drugs, had you shared the needle with other friend?
a. Yes
b. No
15) Have you ever been tested for HIV?
a. Yes
b. No 